\title{
Spatial variation in the incidence of a sexually transmitted parasite of the ladybird beetle Adalia bipunctata (Coleoptera: Coccinellidae)
}

\author{
K. Mary WeBberleY ${ }^{1,2}$, Matthew C. TINSLEY ${ }^{2}$, John J. SLOGGETT ${ }^{2,3}$, Michael E.N. MAJERUS ${ }^{2}$ \\ and GREGORY D.D. HURST ${ }^{1,2}$ \\ ${ }^{1}$ Department of Biology, University College London, 4 Stephenson Way, London NW1 2HE, UK; e-mail: g.hurst@ucl.ac.uk \\ ${ }^{2}$ Department of Genetics, Downing Street, Cambridge, CB2 3EJ, UK \\ ${ }^{3}$ Department of Animal Ecology I, University of Bayreuth, Germany
}

Key words. Coccinellidae, Adalia bipunctata, Coccipolipus hippodamiae, sexual transmission, voltinism, Hesperomyces virescens

\begin{abstract}
Whilst sexually transmitted pathogens and parasites are common on insects and other animals, the factors affecting their incidence are currently uncertain. In order to understand the factors important in determining the presence of sexually transmitted parasites, it would be helpful to have information on intraspecific variation in incidence, as the causes of this variation are likely to reflect the likely causes of the presence/absence of sexually transmitted parasites across species. We therefore mapped the incidence of the parasite Coccipolipus hippodamiae within Europe on its primary host, the ladybird Adalia bipunctata. We observed that $C$. hippodamiae was present widely in Central, Southern and Eastern Europe, but was absent from northerly and north-western populations. The cause of this pattern of incidence variation is discussed, with particular reference to the voltinism of the host. We also note that the distribution of $C$. hippodamiae on A. bipunctata is not congruent with that of another sexually transmitted parasite of this species, Hesperomyces virescens.
\end{abstract}

\section{INTRODUCTION}

Sexually transmitted pathogens and parasites are now recognised in a wide range of animal species. Whilst these have been known for sometime in promiscuous mammals, there is a growing appreciation that they are also common in insects (Knell \& Webberley, 2004). Within insects, most cases of sexually transmitted disease are associated with ectoparasitic fungi, mites and nematodes that are either mechanically transferred during host copulation (in the case of fungi and some nematodes), or transfer actively (in the case of mites and some nematodes). These parasites have a variety of pathological effects, from nearly asymptomatic (Poinar, 1970) through to induction of host sterility (Hurst et al., 1995). They may also attain very high prevalence (Webberley et al., 2006). Where infections attain high prevalence and produce severe pathology, they represent a strong ecological, and potentially evolutionary, force on the species that infect them (Hurst et al., 2005).

The factors dictating the incidence of sexually transmitted infections are as yet undetermined. Promiscuity of the host species is clearly correlated with prevalence in coccinellid beetle-mite interactions (Webberley et al., 2004), and it must be expected that sexually transmitted infections are less likely to persist with increasing tendency to monogamy in the host. Promiscuity may also be affected by density, producing a link between host density and presence/absence of STDs (Ryder et al., 2005). Notwithstanding the above findings, it has also been noted that sexually transmitted infections of insects will be limited to species in which host cohorts overlap, permitting transfer of the pathogen/parasite between generations of the host (Hurst et al., 1995). Insect populations in tem- perate areas typically display voltinism, with cohorts of adults separated in time. If separation is complete, then a sexually transmitted pathogen cannot be maintained.

Separating the role of variation in promiscuity and voltinism in dictating the incidence of sexually transmitted infections in promiscuous temperate insect species will require comparative study. Whilst this analysis could utilize different species as data points, it would be more powerful to investigate spatial variation in incidence within a species, producing fewer uncontrolled ecological and biological factors. Past study of the sexually transmitted haematophagous mite, Coccipolipus hippodamiae, carried by the two spot ladybird, Adalia bipunctata, suggests this interaction is a good candidate for possessing such variation. Whilst previous work has recorded C. hippodamiae presence in Central and Eastern European populations (Hurst et al., 1995; Zakharov \& Eidelberg, 1997; Christian, 2002; Webberley et al., 2004), observations around the United Kingdom over many years have indicated it is absent in this area. It is also interesting by virtue of its combination of high prevalence and virulence (Hurst et al., 1995; Webberley \& Hurst, 2002; Webberley et al., 2006).

In this paper we create an incidence map of C. hippodamiae on $A$. bipunctata within Europe based on sampling over the last 10 years, and published records from the literature. We also compare these to our notes on the incidence of the sexually transmitted ascomycete fungus Hesperomyces virescens on $A$. bipunctata to gain insight into the degree to which the incidence of sexually transmitted parasites are congruent. 


\section{MATERIAL AND METHODS}

Fifty eight collections of 10 or more adult $A$. bipunctata from 40 locations across Europe in the previous 10 years were scored for the presence/absence of $C$. hippodamiae (see Table 1). Scoring of collected individuals for mites followed the protocol described in Webberley et al. (2004). In brief, they were anaesthetized with $\mathrm{CO}_{2}$ or ice and placed with their dorsum against Blu Tac. The elytra were then retracted horizontally away from the body using entomological pins to allow sight of the underside of the elytra, where the mites complete their life cycle. This area was then examined under $\times 40$ magnification for the presence of mites, with both elytra being examined. From this, the individual was scored as either possessing the mite infection, or mite infection being absent. A sample was regarded as being infected if one or more individuals carried the mite, and uninfected only if the mite was absent from all individuals.

To these data were added previous records from Hurst et al., (1995), Zakharov \& Eidelberg (1997) and Christian (2002) to create an incidence map.

\section{RESULTS}

Geographical variation in the incidence of C. hippodamiae is given in Fig. 1. All "core" Central and East European populations were observed to carry this infection. In contrast, the infection was observed to be absent from north-western populations sampled, and populations from Northern Scandinavia. Sampling in this latter context is intense, with sample sizes of $>450$ and $>1200$ at the southernmost points where $C$. hippodamiae is first recorded as absent, making a conclusion of absence in this area reliable. With regard to north-western populations, it is notable that samples relatively close in geographical space (though collected at different times) all independently indicate absence of the mite, again strengthening this result. Finally, we would note three cases of temporal variation in incidence within our study: in Bielefeld and Bayreuth (both Germany) and St Petersburg. In each of these, at least one sample was infected with the mite, but a sample taken from the same region at a different time was not.

\section{DISCUSSION}

Coccipolipus hippodamiae, the sexually transmitted mite infections found on $A$. bipunctata, shows a clear geographic pattern in its incidence, being present widely across the range of its host in Europe, but absent from populations near the north-western coasts, and also from Northern Scandinavia.

The cause of this variation is currently unknown. One possibility is an alteration in voltinism over space. Whilst both previous observation (Ceryngier \& Hodek, 1996), and our own experience (Webberley et al., 2006), indicate this species is multivoltine in Central Europe by virtue of high spring and summer temperatures, this is not commonly observed in the western part of its range (Majerus, 1994). We also made detailed notes on the phenology of A. bipunctata in South and North Scandinavia during $2000 \& 2001$ to compare with mite incidence. In Malmo, (mite present, $55^{\circ} \mathrm{N}$ ) ladybird eggs, larvae and pupae could all typically be observed in early June, reflecting 4 weeks of previous reproductive activity. In Stockholm

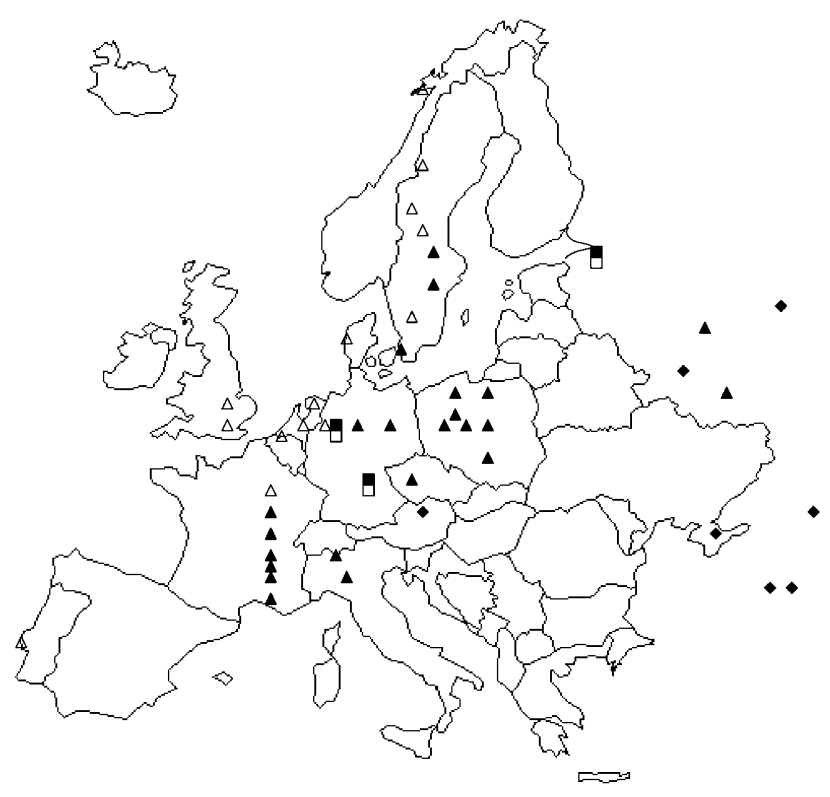

Fig. 1. The incidence of the sexually transmitted parasite $C$. hippodamiae on $A$. bipunctata. Filled triangles represent populations where the mite was present in all samples scored. Empty triangles represent samples where the parasite was absent from all samples scored. Where independent samples indicated presence in one case, and absence in another, this is indicated by a filled box over an unfilled one. Populations known to be infected with the mite from the studies of Christian (2002) and Zakharov \& Eidelberg (1997) are indicated by filled diamonds.

(mite present, $59^{\circ} \mathrm{N}$ ), eggs and larvae were present in early June, and overwintered generation adults could be seen alongside adults of the next generation by $\mathrm{mid} / \mathrm{late}$ June. The activity season lasted approximately 8 months in these southern populations, and the populations were clearly bivoltine, with new adults still emerging in early September. In contrast, in Ostersund and Vilhemina (mite absent, $63^{\circ}$ and $65^{\circ} \mathrm{N}$ respectively), overwintered ladybirds had newly reached food plants in early June, with eggs observed from mid June. The mean length of the $A$. bipunctata activity season was around four months in these northerly populations, and the species here was clearly univoltine.

The correlation between mite incidence and ladybird voltinism is tempting, because sexually transmitted infections require sexual contact between generations in order to persist, and this is likely to correlate with voltinism. Multivoltine reproduction exists in areas with hot spring/summers, where there is reproductive overlap of generations. Univoltine reproduction occurs in more temperate areas, and is likely to be associated with lack of reproductive contact between members of different generations. However, the evidence is correlative and not causal, and it may be that promiscuity or some other factor covaries along this same dimension. Only careful field comparisons in promiscuity levels and levels of inter-generation mating, between proximal populations where the parasite is present and absent, can really establish the factor driving parasite incidence. The loss of infection that occurs in the west of Germany and on 
TABLE 1. Location, date and size of samples of A. bipunctata scored for presence/absence of C. hippodamiae.

\begin{tabular}{|c|c|c|c|}
\hline Country & Location & Date & $\mathrm{n}$ \\
\hline \multirow[t]{7}{*}{ Sweden } & Malmo & June 2001 & 276 \\
\hline & Nassjo & June 2001 & 69 \\
\hline & Stockholm & Sept 2002 & 204 \\
\hline & Gavle & June 2001 & 41 \\
\hline & Ljusdal & Sept 2002 & 1215 \\
\hline & Ostersund & Sept 2002 & 494 \\
\hline & Vilhelmina & June 2001 & 43 \\
\hline Norway & Narvik & Sept 2000 & 84 \\
\hline \multirow[t]{3}{*}{ The Netherlands } & Groningen & March 2005 & 119 \\
\hline & Wageningen & Feb 1996 & 22 \\
\hline & & April 1996 & 90 \\
\hline Belgium & Bruges & April 1996 & 22 \\
\hline \multirow[t]{7}{*}{ France } & Montelimar & June 2002 & $>20$ \\
\hline & Vienne & June 2002 & 26 \\
\hline & Valence & June 2002 & 20 \\
\hline & Lyon & May 2003 & 13 \\
\hline & Macon & June 2002 & 18 \\
\hline & Chaumont & June 2002 & 20 \\
\hline & St Dizier & June 2002 & 16 \\
\hline \multirow[t]{2}{*}{ UK } & London & April-Sept 1998 & $>500$ \\
\hline & Cambridge & 1995-1997 & $>500$ \\
\hline \multirow[t]{12}{*}{ Germany } & Munster & Oct. 1996 & 16 \\
\hline & Bayreuth & April-May 2005 & $>100$ \\
\hline & & Sept.-Oct. 2004 & 71 \\
\hline & & March 1997 & 64 \\
\hline & Bielefeld & July 1995 & 61 \\
\hline & & July 1996 & 103 \\
\hline & & May-June 1997 & 84 \\
\hline & Braunschweig & July 1996 & 43 \\
\hline & & April-June 2000 & 1101 \\
\hline & Berlin & Aug. 1995 & 13 \\
\hline & & July 1996 & 89 \\
\hline & & May 1997 & 24 \\
\hline \multirow[t]{13}{*}{ Poland } & Olsztyn & July 1995 & 17 \\
\hline & Poznan & Aug. 1995 & 16 \\
\hline & & July-Aug. 1996 & 45 \\
\hline & & July 1997 & 184 \\
\hline & Torun & August 1995 & 38 \\
\hline & & July 1996 & 45 \\
\hline & & June-July 1997 & 313 \\
\hline & Warsaw & August 1995 & 17 \\
\hline & & July 1997 & 77 \\
\hline & & June-July 1997 & 116 \\
\hline & Krakow & August 1996 & 11 \\
\hline & Kutno & July 1996 & 12 \\
\hline & Gniezno & June 1997 & 30 \\
\hline Czech republic & Prague & June-Oct. 1996 & 62 \\
\hline Denmark & Ribe & September 1996 & 46 \\
\hline \multirow[t]{7}{*}{ Russia } & St Petersburg & August 1996 & 32 \\
\hline & & July 1997 & 168 \\
\hline & & July 2000 & $>20$ \\
\hline & Moscow & August 1996 & 16 \\
\hline & & July 1997 & 227 \\
\hline & & July 2000 & $>20$ \\
\hline & Voronezh & July 2000 & $>20$ \\
\hline \multirow[t]{2}{*}{ Italy } & Parma & September 1996 & 37 \\
\hline & Novara & Summer 1996 & 33 \\
\hline Portugal & Lisbon & June 2005 & 66 \\
\hline
\end{tabular}


moving north in Scandinavia would be very suitable for this type of study.

Our study revealed three cases of variation in mite presence/absence between samples collected at different times within a location (in Bielefeld, Bayreuth and St Petersburg). In one case (Bayreuth, Germany), the mite was observed to be absent from one sample, and present in others. The single record of absence in this population is likely to be attributable to sampling at a time of year when prevalence is very low. We have observed that mite prevalence during overwintering can be very low, with prevalence climbing through spring (J.J. Sloggett, pers. observ. in Bayreuth; K.M. Webberley, pers. observ. in Braunschweig). Samples taken from overwintering sites, or in very early spring, would need to be very large to be faithfully used as an indicator of mite absence. We thus do not believe the absence from this one sample signifies true temporal variation in incidence in this population. In contrast, we believe the records of mite absence in Bielefeld (Germany), and St Petersburg (Russia), do reflect a real absence of the infection from those locations at those times. In the case of Bielefeld, Germany, the three samples collected all fell in the spring/early summer period when mite prevalence is at its highest, and indeed in the one sample where the mite was detected, prevalence was $44 \%(n=61$, July 1995). The absence of the mite in June 1996 and July 1997 (with large sample size, at a similar time of year to the former sample where the mite was common) is in this case likely to reflect a real absence. St Petersburg, where mite presence was usual, but absence was recorded in July 1997 with a sample size in excess of 160 , is likely to reflect similar temporal variation in incidence. We regard these two populations as ones where the mite cannot persist indefinitely, but does exist in suitable years, with reinfection of the population via ladybirds migrating in from neighbouring populations that are permanently infected. We therefore conclude that the spatial range of the parasite shows temporal variation.

The spatial range of $C$. hippodamiae on $A$. bipunctata differs from that of $H$. virescens, a sexually transmitted ectoparasitic fungus additionally found on A. bipunctata. $H$. virescens has been recorded as common in London (Weir \& Beakes, 1996; Welch et al., 2001), and Vienna (Christian, 2001). We have also noted its presence within our samples in Parma (Italy) (G.D.D. Hurst, pers. observ.), Novara (Italy), Braunschweig and Berlin (Germany) (K.M. Webberley, pers. observ.), Lyon and Bayreuth (J.J. Sloggett, pers. observ.) and Stockholm (M.C. Tinsley, pers. observ.). It has also been recorded in Utrecht (S. Lommen \& K. Koops, pers. comm.). Whilst it is hard to prove absence of this infection (it is only readily scorable when the fungus is fruiting, hence the presentation of these results in note form), we do note the absence of infection during intense sampling in Torun, Poland ( $>4000$ beetles scored, survey from May-September, over four years) (K.M. Webberley, pers. observ.).

This pattern was surprising to us. Given both C. hippodamiae and $H$. virescens are sexually transmitted pathogens, it would be expected that either they would have identical geographic ranges, or one would have a range contained within the other (if for instance that parasite was transmitted less efficiently during copulation, or had a longer latent period). However, this is not the case. There exist both populations with $H$. virescens but without C. hippodamiae (e.g., London, the Utrecht/ Wageningen region of the Netherlands), and populations with $C$. hippodamiae but without $H$. virescens (e.g., Torun, Poland). The difference is even more pronounced when seen in terms of prevalence achieved by the parasite that is present. Torun in Poland (H. virescens absent) is a site where infection prevalence of $C$. hippodamiae reaches $90 \%$ of adult beetles each year (Webberley et al., 2006). In London (C. hippodamiae absent), $H$. virescens is very common in spring, with $>50 \%$ of adult beetles showing sign of infection (Welch et al., 2001). The reasons for this incongruence in range remains for future investigation.

ACKNOWLEDGEMENTS. We wish to thank the NERC, BBSRC and BES for funding the collections made in various parts of this project. We wish to thank A. Manica, A. Johnson, I. Zeistra, E. Purvis and W. Völkl for assistance in collection and $\mathrm{S}$. Lommen and $\mathrm{K}$. Koops for sharing observations on H. virescens.

\section{REFERENCES}

Christian E. 2001: The coccinellid parasite Hesperomyces virescens and further species of the order Laboulbeniales (Ascomycotina) new to Austria. Ann. Naturhist. Mus. Wien (B) 103: 599-603.

Christian E. 2002: Zur Verbreitung und Lebensweise des Marienkäfer-Parasiten Coccipolipus hippodamiae (McDaniel \& Morrill, 1969) (Acari, Podapolipidae). Abh. Ber. Naturkundemus. Görlitz 74: 9-14.

Ceryngier P. \& Hodek I. 1996: Enemies of Coccinellidae. In Hodek I. \& Honěk I. (eds): Ecology of Coccinellidae. Kluwer Academic, London, pp. 319-350.

Hurst G.D.D., Sharpe R.G., Broomfield A.H., Walker L.E., Majerus T.M.O., Zakharov I.A. \& Majerus M.E.N. 1995: Sexually transmitted disease in a promiscuous insect, Adalia bipunctata. Ecol. Entomol. 20: 230-236.

Hurst G.D.D., Webberley K.M. \& KNell R. 2005: The role of parasites of insect reproduction in the diversification of insect reproductive processes. In Fellowes M.D.E., Holloway G. \& Rolff J. (eds): Insect Evolutionary Ecology. CABI Bioscience, Wallingford, pp. 205-229.

KNell R.J. \& Webberley K.M. 2004: Sexually transmitted diseases of insects: distribution, ecology, evolution and host behaviour. Biol. Rev. 79: 557-581.

MaJerus M.E.N. 1994: Ladybirds. Harper-Collins, London, 367 pp.

PoINAR G.O.J. 1970: Orycetonema genitalis gen. et sp. nov. (Rhabditidae: Nematoda) from the genital system of Orycetes monoceros L. (Scarabaeidae: Coleoptera) in West Africa. $J$. Helminthol. 44: 1-10.

Ryder J.J., Webberley K.M., Boots M. \& Knell R.J. 2005: Measuring the transmission dynamics of a sexually transmitted disease. Proc. Natl. Acad. Sci. USA 102: $15140-15143$.

WebBerLey K.M. \& Hurst G.D.D. 2002: The effect of aggregative overwintering on an insect sexually transmitted parasite system. J. Parasitol. 88: 707-712. 
Webberley K.M., Hurst G.D.D., Husband R.W., Schulenburg J.H.G., Sloggett J.J., Isham V., Buszko J. \& Majerus M.E.N. 2004: Host reproduction and a sexually transmitted disease: causes and consequences of Coccipolipus hippodamiae distribution on coccinellid beetles. J. Anim. Ecol. 73: 1-10.

Webberley K.M., Buszko J., Isham V. \& Hurst G.D.D. 2006 Sexually transmitted disease epidemics in a natural insect population. J. Anim. Ecol. 75: 33-43.

WeIR A. \& Beakes G.W. 1996: Correlative light- and scanning electron microscope studies on the developmental morphology of Hesperomyces virescens Thaxt. Mycologia 88: 677-693.
Welch V.L., Sloggett J.J., Webberley K.M. \& Hurst G.D.D. 2001: Short-range clinal variation in the prevalence of a sexually transmitted fungus associated with urbanisation. Ecol. Entomol. 26: 547-550.

ZaKharov I.A. \& Eidelberg M.M. 1997: Parasitic mite Coccipolipus hippodamiae McDaniel \& Morrill (Tarsonema, Podapolipidae) in populations of the two spotted ladybird Adalia bipunctata L. (Coleoptera, Coccinellidae). Entomol. Obozr. 76: $680-683$.

Received November 25, 2005; revised and accepted July 4, 2006 